\title{
DELOVANJE TERITORIALNE OBRAMBE NA OBMOČJU LJUTOMERA, ORMOŽA IN GORNJE RADGONE V VOJNI 1991
}

\author{
Ljubo Dražnik*
}

Izvleček:

UDK: $911: 355.3 \% .4(497.4-11)$

Leto 1991 bo za vedno zapisano v slovensko zgodovino. Predstavlja mejnik med dvema dobama in izkušnjo, ki bo za zmeraj vtisnjena v narodov zgodovinski spomin. Ta spomin bo pravi in pravilen le, če bo predstavil tiste razmere verno, nepristransko in uravnoteženo. Takšen prikaz razmer pa ni pomemben samo za Slovenijo v celoti, ampak tudi za dogajanja $v$ njenih pokrajinah. Pomemben delež, predvsem na področju oboroženega boja, so dali pripadniki teritorialne obrambe (TO), policisti in prebivalstvo na območju, ki je po vojaški odgovornosti spadalo pod 73. Območno poveljstvo TO Ljutomer. Spopadi v Ormožu, Kačurah, Banfiju, Gibini, Presiki, Pristavi, Ljutomeru, Stari Novi vasi, Radencih, Gornji Radgoni ter drugih krajih dokazujejo pripravljenost ljudi braniti svoje prepričanje, dom in domovino. Na uspehe in neuspehe TO je v veliki meri vplival geografski dejavnik. Za vojaško stroko je še posebej pomembno, da se opravi analiza tega območja na osnovi praktične izkušnje, ki smo jo Slovenci doživeli v letu 1991. S tem bomo dopolnili mozaik razumevanja vojaškega uspeha $v$ tej vojni, ki bo pravi le, če bo predstavil tedanje razmere verno, nepristransko in uravnoteženo.

Ključne besede: TO (teritorialna obramba), JLA (jugoslovanska ljudska armada), v/o (vojaški obveznik)

\section{ENGAGEMENT OF TERRITORIAL DEFENSE FORCES DURING THE WAR IN 1991 IN THE AREAS OF LJUTOMER, ORMOž AND GORNJA RADGONA}

\begin{abstract}
The year 1991 is unforgettable in the Slovenian history. It is a milestone dividing two eras and an invaluable lesson learned, forever engraved in the nation's historical memory. Events from 1991 ought to be presented objectively, impartially, and in a balanced manner. Such presentation of the circumstances is important not only for Slovenia as a whole, but also for the events that took place in individual regions. An important contribution, particularly in terms of armed resistance, was given by Territorial Defense (TD) troops, police officers and inhabitants of the area under the $73^{\text {rd }}$ TD Ljutomer's District Command area of responsibility. The conflicts in Ormož, Kačure, Banfi, Gibini, Presika, Pristava, Ljutomer, Stara Nova vas, Radenci, Gornja Radgona and other places confirmed people's preparedness to fight for their beliefs, their homes and their homeland. Both successes and failures of TD were influenced by geographical factors to a significant extent.

It is very important for the military to conduct an area analysis based on the practical experience of the Slovenes from 1991. This will help complement the mosaic of understanding of the military success in this war and will reflect reality only if the events are described objectively and in a balanced manner.
\end{abstract}

Key words: Territorial Defense (TD), Yugoslav People's Army (YPA), conscripts

* Podpolkovnik, univerzitetni diplomiran obramboslovec, poveljnik. 82. brigade Slovenske vojske. 


\section{UVOD}

Namen analize vojaških spopadov iz vojne 1991 je predstaviti kronološko- sintetičen opis dogodkov na območju 73. Območnega štaba teritorialne obrambe (Obm. ŠTO) Ljutomer, da ne bi ostali v spominu zapisani zamegljeno in pristransko.

Najpomembnejši razlogi za pripravo podrobne analize so:

- Določena časovna razdalja omogoča, da se trezno in na podlagi dejstev opravi opis takratnih dogodkov.

- V tem času so se nabrala nova spoznanja, ki v marsičem pojasnjujejo tedanji potek dogodkov.

- Različne interpretacije zahtevajo enotno pojasnitev. Vojak, poveljnik enote, poveljnik Območja imajo objektivno različen pogled na pomen in vlogo enot in posameznikov $\mathrm{v}$ tistem času.

- Analiza tedanjih dogodkov omogoča enotam in vojakom TO lažje razumevanje tedanjih ukrepov nadrejenega poveljstva in ovrednotenje lastnega prispevka k celotnemu prispevku na bojišču.

- Borbe in boji na območju 73. Obm. ŠTO predstavljajo del novejše slovenske vojaške zgodovine in zahtevajo analitičen pristop pri opisu tedanjih dogodkov.

- Ti boji predstavljajo praktične izkušnje, ki jih lahko upoštevamo pri usposabljanju pripadnikov SV.

- Oblike oboroženega boja, organiziranost in rezultati imajo določen vpliv na nadaljnji razvoj obrambne organiziranosti $\vee$ Sloveniji.

Pri izdelavi analize je bilo upoštevano celotno arhivsko gradivo, ki je v Območnem poveljstvu, kot so povelja, ukazi, informacije, dnevna poročila, karte, itd.. Uporabljeni so bili opisi spopadov, ki so jih napisali poveljniki enot, ustna pričevanja vojakov in civilistov, ki so bili priče določenega dogodka, in ostalo gradivo, pomembno za osvetlitev tedanjih dogodkov, kot je pisanje spominov častnikov in vojakov JLA, izpisi iz revij in časopisov ter drugih oblik informiranja.

Analiza s tem še ni zaključena. Nadaljevati jo bo potrebno po nižjih enotah. Pri tem bodo morali svoje prispevati častniki, nižji častniki in vojaki iz teh enot. Za realno oceno bi bilo potrebno imeti še analizo teh dogodkov tudi s strani nadrejenega poveljstva, to je 7 . PŠTO (Pokrajinskega štaba teritorialne obrambe).

\section{ORGANIZACIJA IN PRIPRAVA 73. OBM ŠTO PRED VOJNO}

Obdobje pred junijsko - julijsko vojno je zaznamoval čas velikih sprememb v organiziranosti Teritorialne obrambe (TO). S 1. junijem 1991 so se ukinili Občinski štabi TO (OŠTO) in organizirali Obm. ŠTO. Obm. ŠTO Ljutomer je tako obsegal območje občin Gornja Radgona, Ormož in Ljutomer. Nova organiziranost je prinesla velike kadrovske spremembe. Število delavcev na Obm. ŠTO se je v primerjavi s seštevkom delavcev v prejšnjih OŠTO občutno zmanjšalo. Zaradi objektivnih vzrokov (izobrazbena struktura, vojaška evidenčna dolžnost (VED), potrebe Pokrajinskega štaba TO (PŠTO) ni bilo mogoče v celoti upoštevati teritorialnega principa zaposlitve. Vse to je predstavljajo določeno slabost, ker je bila tedanja TO organizirana po formacijah, ki so bile ustanovljene v času delovanja manevrske strukture Narodne zaščite. Formacije so bile narejene različno upoštevajoč kader, orožje in ostale razmere 
določenega OŠTO. Predvideni so bili določeni ukrepi tajnosti, ko je šlo za izbiro ljudi. Zanesljivost je temeljila na osebni presoji. Na notranjo organiziranost 73 . Obm. ŠTO sta vplivali še velikost in razporeditev enot TO. Tako je $73 \mathrm{Obm}$. ŠTO imel v sestavi 16 samostojnih enot z 680 v/o (vojaških obveznikov).

Enote so bile formirane glede na število orožja, ki je bilo od septembra 1990 ponovno v skladiščih TO. Za uspešno vodenje in poveljevanje je bilo enôt preveč. Kljub temu je ostalo njihovo število in velikost nespremenjeno, saj bi spreminjanje v tistem času imelo negativen vpliv na bojno pripravljenost 73. Obm. ŠTO.

Dopolnila se je organizacija vodenja in poveljevanja s strani štaba. Tako je organiziralo glavno poveljstvo v Ljutomeru ${ }^{1}$, med tem ko sta se v Gornji Radgoni in Ormožu ustanovili izpostavljeni poveljstvi $\mathrm{z}$ nalogo, da neposredno poveljujeta enotam na njihovem območju, podrejeni pa sta bili neposredno Obm. ŠTO. Ocene poveljstva v tistem trenutku so bile, da se s takšno notranjo organiziranostjo lahko zagotovijo pogoji za uspešen oboroženi odpor.

$\mathrm{V}$ vojni se je številčna struktura menjala glede na zahtevnost nalog na posameznem območju. V prvem dnevu vojne, 27. 06., je bila večina stalne sestave v Ormožu in pri enotah v Ljutomeru. Na štabu je bil samo načelnik RAUTER Mirko. V drugem delu vojne, od 2. in 3. 7. je bilo največ pripadnikov stalne sestave v Gornji Radgoni, medtem ko je v tem času bil na poveljstvu v Ljutomeru od stalne sestave $\mathrm{v}$ glavnem samo poveljnik območja DRAŽNIK Ljubo, ker so ostali člani morali opravljati pomembne naloge na terenu (prevzem orožja, prevzem enote iz Slovenskih Konjic, usposabljanje pripadnikov z novimi protioklepnimi sredstvi). Po spopadu v Ormožu je BRATKOVIČ Branko prevzel naloge usposabljanja na območju občine Ljutomer, zato je vlogo koordinatorja bojev na območju občine Ormož vodil ŠTAMPAR Aleksander. Kljub temu ostaja ocena, da je v tistem času samo ta oblika organiziranja lahko prinesla rezultate, saj je omogočila, da so bili pripadniki stalne sestave tam, kjer so poznali teren in ljudi ter načrte za uporabo enot.

\section{PRIPRAVE NA OBOROŽENI ODPOR}

Predpriprave so potekale v dokaj neugodnih družbeno političnih razmerah. V Sloveniji se je veliko govorilo o demilitarizaciji. Ne glede na dokaj težke razmere je območnemu štabu $\mathrm{v}$ prehodnem času uspelo vključiti in motivirati vse institucije, pomembne za oboroženi boj. Pomembno je bilo sodelovanje s policijo, upravnimi organi za obrambo in organi oblasti. Sodelovanje med policijo in TO je bilo dobro. Cilji so bili skupni, koordinacija je bila odlična. Informacije so bile točne in sprotne, seznanitev z dogajanji je bila dobra. Vsi ti dejavniki so imeli svoj pozitivni odraz v vojni.

Težišče aktivnosti v tistem času je bilo načrtovanje (načrta ${ }^{2}$ : JEZERO, KAMEN) in obrambno domovinska priprava pripadnikov. $\mathrm{V}$ ta namen je poveljnik območja skupaj z vodstvi

1 Pri kadrovanju v posamezna poveljstva se je maksimalno upoštevala teritorialna pripadnost pripadnikov stalne sestave. Tako so bili v Ljutomert trije člani iz. nekdanjega OŠTO Ljutomer in eden iz. Lendave, v Gornji Radgoni dva člana iz. Gornje Radgone in eden iz. Lendave in v Ormožu eden iz. Ormoža in eden iz. Lendave. Organizacijska struktura izpostavljenih poveljstev se je preko upravnih organov za obrambo dopolnila še z. rezervno sestavo tako, da je bilo izpostavljeno poveljstvo skupno sestavljeno iz treh častnikov, dveh podčastnikov in šest vojakov.

2 Načrti, ki so imeli neposreden vpliv na izvajanje kasnejših bojnih dejstvovanj so bili izdelani v prvi polovici leta 199I. To so bili načrt »Kamen I - 4«, načrt »Jezero« in usposabljanje na vaji »KOBRA - 9I". 
posameznih občin obiskal vse enote in z njimi opravil informacijske sestanke. Ti posveti s kolektivi enot so bili zelo pomembni. Imeli so velik propagandni in psihološki učinek. Povečali so zaupanje pripadnikov v starešinski kader, posebej profesionalni. Pripadniki stalne sestave so $v$ tistem času intenzivno delali na organizaciji, opremljanju in usposabljanju enot ter pridobivanju obveščevalnih podatkov o aktivnostih nasprotnika.

\section{ANALIZA BOJNIH DELOVANJ V VOJNI 1991}

\section{Analiza delovanja enot JLA na območju 73. Obm.ŠTO Ljutomer}

Kljub pomanjkanju uradnih dokumentov, kot so povelja in ukazi, ki jih je v času vojne izdelal nasprotnik, pa je na razpolago že toliko pisnih dokumentov, da lahko dokaj verodostojno obravnavamo njegove namere in analiziramo potek izvajanja nalog. Pisna sporočila, ki predstavljajo pomožno gradivo pri oblikovanju presoje, so objave spominov vodilnih častnikov JLA, njihova pričevanja na sodiščih po vojni, opis teh dogodkov v reviji Naša obramba in ustna pričevanja. Drugi pomemben vir presoje pa predstavljata premik in potek spopadov z enotami JLA.

V januarju 1991 so na poveljstvih JLA pripravili različico vojnega načrta, kako v primeru odcepitve Slovenije zasesti meje z Avstrijo in Italijo ter zagotoviti nadaljnjo celovitost ozemlja SFRJ (NIN, 51). Po šestih mesecih so ta načrt izvedli v težkih in neugodnih razmerah. V mesecu maju je prišlo do kadrovskih sprememb v Varaždinskem korpusu, kjer je generala Jevrema Cokica zamenjal general Vlada Trifunovic. 25. junija je Slovenija razglasila neodvisnost in vzpostavila nadzor nad mejnimi prehodi. Nalogo, da se odstrani mejni prehod v Središču ob Dravi in zagotovi kontrolo na mejnem prehodu v Gornji Radgoni, je dobila 32. mehanizirana brigada iz Varaždina pod poveljstvom polkovnika Popova (Narodna Armija, 22). Razmišljanja o zavzetju mejnega prehoda v Gornji Radgoni z zračnim desantom so bila v vodstvu 5. armadnega območja odbita. V času od 25. do 26. 6. 1991 so organizirali oglede novo nastalih mejnih prehodov z izvidniškimi patruljami.

\section{Prvi del vojne od 27. do 29. 6. 1991}

Zamisel napada enot JLA je obsegala uporabo glavnih in pomožnih sil. Glavne sile je predstavljala oklepno mehanizirana četa ( 5 tankov in 10 oklepnih transporterjev), ki je na smeri Varaždin - Ormož - Ljutomer - G.Radgona skušala zagotovi nadzor nad mejnim prehodom. Pomožne sile je predstavljala izvidniška četa z nalogo, da zagotovi nadzor nad prehodi čez reko Muro (NIN, 51). Ostali del oklepno mehanizirane brigade je bil v rezervi.

Potek:

V zgodnjih jutranjih urah, 27. 6. 1991, je dobil poveljnik 32. mehanizirane brigade ukaz za premik iz Varaždina prek Ljutomera do Gornje Radgone z nalogo, da zagotovi nadzor nad državnim mejnim prehodom. Za to nalogo je poveljnik brigade uporabil 5 tankov in 10 oklepnih transporterjev (ki so bili oboroženi $7.20 \mathrm{~mm}$ topovi, mitraljezi $7,62 \mathrm{~mm}$ in protioklepnimi raketami). Kolona se je zaustavila pred mostom čez Dravo pri Ormožu, kjer je bila postavljena barikada, narejena iz gradbenih strojev in tovornjakov vlačilcev. Prišlo je do pogajanj s TO, ki niso bila uspešna. 
Pogajanja in čakanje na ukaze nadrejenega poveljstva je trajalo približno 4 ure. Ob 12. uri je $\mathrm{s}$ helikopterjem priletel načelnik mariborskega korpusa polkovnik Stojanovski z zahtevo, da čim prej krenejo na mejo, kjer naj bi se dogajale strašne stvari. Prišlo je do spopada. Iz tankov in oklepnih transporterjev so pričeli streljati. Ker prehod prek mosta ni bil mogoč, je prišlo do spremembe načrta. General Trifunović je poslal prek Središča ob Dravi po levi strani Drave četo, sestavljeno iz 10 tankov z nalogo, da razruši mejni prehod pri Središču ob Dravi, odstrani barikado na mostu v Ormožu ter prodira proti Ljutomeru, veže nase enote TO in tako omogoči lažji prodor glavne kolone proti Gornji Radgoni. Trifunović je že prej sprejel novi predlog polkovnika Popova, da izvede prodor prek Razkrižja, kjer ga Slovenci ne pričakujejo (NIN, 51). Po sprejetju tega ukaza se je Popov vrnil v Varaždin, na novo organiziral enoto iz 3 tankov, 11 oklepnih transporterjev, 7 kamionov, 2 cistern in 2 vozil za zvezo ter začel po stranskih poteh prodirati proti Sloveniji.

Kolona, sestavljena iz 9 tankov, je 27. 6. ob 13.30 razrušila mejni prehod pred Središčem ob Dravi in ob 14.10 uri prebila barikado v Pušencih. V Ormož je prispela ob 15.00 uri in poskusila odstraniti barikado na mostu. Naloge niso opravili, zadržale so jih branjene ovire, kombinirane $z$ minami v centru Ormoža. Prišlo je do spopada. Z »armbrustom « je bil zadet prvi tank. Enota se je potem umaknila izven Ormoža in nadaljevala prodiranje proti Ljutomeru. Zvečer ob 22.00 uri je prišlo do spopada pri Kačurah. Ovire iz podrtih dreves na glavni komunikaciji in branjene $\mathrm{z}$ dvema vodoma TO, jim ni uspelo prebiti, zato so jo hoteli zaobiti prek vasi Mekotnjak. Tu je prišlo do ponovnega spopada. En tank je bil zadet. Prodor na tej smeri je bil zaustavljen. Ta enota se je potem v zgodnjih jutranjih urah 28, 6. umaknila proti Varaždinu.

Kolona, sestavljena iz 3 tankov, 11 oklepnih transporterjev, 7 tovornjakov, 2 cistern in 2 vozil za zvezo, je v večernih urah 27. 6. prodirala v smeri Štrigove na Hrvaškem. Ker sta 1. in 2. kolona vezali veliko enot TO, ostale pa v skladu z načrtom »KAMEN« branile mostove na reki Muri, je tej koloni uspelo prek Razkrižja prodreti do Veržeja, kjer je organizirala krajši počitek. Tisto noč je lilo kot iz škafa. Pot so nadaljevali 28. 6. ob 4.00 uri. Po spopadih pred Veržejem in za njim, kjer so delovale tri protioklepne skupine TO, premaganih ovirah v Hrastju, spopadih v Radencih, kjer je bil smrtno zadet zastavnik Mustafa ter spopadih pred Gornjo Radgono in v samem mestu, je tej koloni ob velikih izgubah ${ }^{3}$ ljudi in opreme uspelo zasesti mejni prehod.

Kolona, sestavljena iz izvidniške čete, 32. mehanizirane brigade 4 je začela s premikom 28. 6. ob 10.30 uri iz Varaždina proti Murskemu Središču. V Murskem Središču je ob 15.00 prišlo do pogajanj s pripadniki TO, ki so branili most na Muri. Ker je bila na mostu barikada sestavljena iz kamionov s cisternami goriva, ki so onemogočale prehod čez most, se je poveljnik izvidniške čete odločil, da nadaljuje prodor v smeri

$3 V$ teh spopadih je imela ta kolona 2 mrtva, večc ranjenih, večcino tovornjakov in ostalih vozil so pripadniki TO uničili ali zajeli.

4 Sestavljena je bila iz. 3 tankov, 4 oklepnih transporterjev, 5 tovornjakov, I cisterne in I vozila za zvezo. V sestavi te enote sta bila tudi dva pehotna voda. Naloge in cilj te enote so najmanj jasni. Dvom v pravilnost uporabe izvidniške čcete, ki je delovala v smeri Varaždin - Mursko Središce, je opisal v svojih spominih tudi polkovnik Popov (NIN, 5I). Odločitev o tem je bila sprejeta v poveljstvu korpusa. Iz. njenega delovanje lahko sklepamo, da je bil med cilji tudi preboj prek mostov na Muri. 
Razkrižja s ciljem, omogočiti prehod čez most na Muri pri Srednji Bistrici. Ob 18.30 uri je prišlo do spopada v vasi Gibina, na meji med Slovenijo in Hrvaško. Tu je imela izvidniška četa dva mrtva in več ranjenih (Narodna Armija, 2). Po tem spopadu se je njen poveljnik odločil za prodor po cesti Štrigova - Banfi. V poznih večernih urah je prišlo do spopada v Banfiju. Ker je bila branjena ovira nepremostljiva, so odstopili od nadaljnjega prodiranja proti Sloveniji. Z manjšo kolono, sestavljeno iz treh tankov in dveh oklopnih transporterjev so poskusili še prodor po poljski poti prek Banfija do Veščice. Nadaljnje bojne aktivnosti je zaustavilo premirje objavljeno v zgodnjih jutranjih urah.

Ocena delovanja JLA v tem obdobju:

Naloga, ki jo je dobil poveljnik brigade, je bila le delno realizirana. Mednarodni mejni prehod v Gornji Radgoni je bil ob velikih izgubah pod nadzorom JLA, to pa je bilo tudi vse, kar so dosegli. Glavne komunikacije in prostor je skoraj v celoti nadzorovala TO. Tako se je relativni uspeh JLA prevesil v svoje nasprotje. Enota na mejnem prehodu je postala ujetnik TO, prepuščena sama sebi. Zaradi izgub med vojaki in uničene opreme je bila morala $v$ enotah JLA vedno manjša. Veliko je bilo prebegov k TO Slovenije. Zaključimo lahko, da so bile enote JLA kljub začetni iniciativi veliki poraženec, v prvem delu vojne na območju 73. Obm. ŠTO.

\section{Drugi del vojne od 2. do 3. 7. 1991}

Zamisel delovanja enot JLA je obsegala načrt za rešitev enote polkovnika Popova iz Gornje Radgone. Generalu Avramoviću, (ki v tem času zamenja generala Kolška) je Trifunović predlagal, spust desanta na Gornjo Radgono, da bi odvrnili pozornost TO od mejnega prehoda in tako omogočili preboj enoti polkovnika Popova. Pri teh bojnih aktivnostih bi moralo sodelovati tudi letalstvo. Vendar zamisel ni bila sprejeta. Ukazano je bilo, da omogoči preboj iz Gornje Radgone močna kombinirana enota (Večer, 25). Njeno jedro so sestavljali pripadniki motorizirane brigade iz Bjelovarja, oklepna sredstva pa so popolnili iz 32. mehanizirane brigade iz Varaždina.

Zamisel o uporabi enot je bila naslednja. Glavne sile bodo delovale v smeri Središče ob Dravi - Ljutomer - Gornja Radgona z nalogo, da omogočijo preboj in vrnitev enote na mejnem prehodu v Gornji Radgoni. Pomožne sile bodo istočasno z glavnimi delovale v smeri Martin ob Muri - Gibina - Razkrižje s ciljem, zagotoviti nadzor nad komunikacijo Ljutomer - Murska Sobota, vezati nase sile TO in omogočiti realizacijo naloge glavnih sil. V primeru zaostrenega stanja na bojišču so predvideli še dodatno enoto za intervencijo, da omogoči izvršitev naloge glavnim silam.

Potek:

Glavna kolona, sestavljena iz 6 tankov, 7 oklepnih transporterjev, 8 tovornjakov, 2 cistern, 1 dvigala, in 2 vozil za zvezo je začela svoj prodor 2. 7. ob 13.00 uri z mejnega prehoda Središče ob Dravi prek Ljutomersko - Ormoških goric proti Ljutomeru. Premik je bilo načrtovan po vzporednih poteh na tej smeri. Do prvega spopada je prišlo v Loperšicah. Ker je mina iz »armbrusta« zgrešila, ni bilo hujših posledic. Do naslednjega spopada je prišlo v Presiki. Zaseda na tem območju je bila zelo učinkovita. V dveurnem spopadu je imela enota JLA 3 mrtve, več ranjenih, uničen 1 tank in 2 oklepna transporterja. Kolona JLA je kljub temu prodrla do Stročje vasi, kjer je ob 23.15 uri organizirala počitek. Bojne aktivnosti so nadaljevali 3. 7. v zgodnjih jutra- 
njih urah. Ob 4.00 uri je prišlo do spopada v Pristavi. Kolona treh tankov in dveh oklepnih transporterjev, ki je predstavljala čelni del, je prodirala naprej z nalogo, da obide Ljutomer in nadaljuje prodor proti Križevcem. Na vpadnici Cven - Ljutomer, pri železniškem križišču v Ljutomeru, je prišlo do spopada s TO, kjer so izgubili tank. Zato je kolona JLA prodiranje po tej smeri opustila in nadaljevala prodor proti Križevcem prek vasi Babinci in Lukavci. Pri prodiranju proti meji z Avstrijo je prišlo do spopadov v območju vasi Bučečovci. Zadnji spopad se je končal ob 14.30 uri pred Radenci, kjer je bil uničen oklepni transporter, en vojak JLA je bil mrtev in več ranjenih. Po tem spopadu je nastopilo premirje.

2. kolona je začela prodirati na pomožni smeri Železna Gora - Martin ob Muri Gibina, z nalogo, vzpostavitve nadzora nad prehodi čez reko Muro in vezave sil TO, da bi omogočili lažjo izvedbo naloge glavnim silam. Sestavljali so jo 4 tanki, 5 oklepnih transporterjev, 3 tovornjaki in 2 terenski vozili. Do spopada je prišlo 2. 7 . ob 16.45 uri pred naseljem Gibina. Zaradi močnega oviranje in odpora branilcev je bil prodor zaustavljen. Napadalci so utrpeli znatne izgube. Ker prodor prek Banfija ni bil mogoč, so se razmestili v bližini Štrigove in se naslednji dan vrnili v Varaždin.

3. kolona, sestavljena iz 3 tankov, 7 oklepnih transporterjev, 2 tovornjakov in 4 manjših vozil je 3. 7. ob 2.30 uri začela prodor na smeri Središče ob Dravi - Kog Ljutomer z nalogo, da omogoči nadzor nad cesto Središče ob Dravi - Ljutomer, veže nase sile TO in tako omogoči realizacijo naloge glavni koloni. Vzrok, ki je pogojeval vključitev te kolone v spopade, so bili problemi pri prodiranju glavne kolone in težko stanje enote na mejnem prehodu v Gornji Radgoni. Tam je prišlo prejšnji dan v popoldanskih urah do spopada z enotami TO. Ob 10.45 uri je prišlo do spopada v naselju Bajzek. V tem spopadu je bil en tank zadet, drugi je zdrsnil pod cestišče, zato ga je posadka zapustila. Po tem so se vrnili na Hrvaško in na svoji poti razdejali civilne objekte na Kogu in Jastrebcih.

2. 7. ob 16.00 uri je prišlo do oboroženega spopada v Gornji Radgoni. Pri tem spopadu so pripadniki TO zasedli obe stražnici v občini Gornja Radgona. Zato je bil položaj enote polkovnika Popova vedno težji, saj je ostala na tem območju popolnoma osamljena. Položaj se je razrešil po ukazanem premirju, ko so lahko vojaki JLA zapustili to območje.

\section{Zaključek}

Boljše razumevanje takratnih dogodkov, kljub nekaterim razlikam v pojasnjevanju, ponazori razmišljanje glavnih poveljujočih o vzrokih in posledicah vojaškega spopada na tem območju.

Polkovnik Popov je v svoji izpovedi za NIN zaključil takole (prevod citata NIN, 51): »Natančno tako kot sem v januarju 1991 risal na karto, kako se bomo premikali proti meji, so nas čakali Janševi teritorialci. Realizacija tega načrta ni bila predvidena s tako malimi silami. Načrtovano je bilo, da bo v akciji sodelovala celotna 32. mehanizirana brigada, in ne samo njene tri čete: izvidniška, mehanizirana in oklepna. Žal je bila celo oklepna četa razdeljena na dva dela. Vzel sem pet tankov, od katerih sta dva ostala pred Ormožem. Drugih pet, ki sem jih pustil Trifunovicu, so nam pozneje poslali na pomoč. Obtičali so na barikadah in se pozneje le s težavo izvlekli. 
Izvidniška četa se ni premaknila dalje od Murskega Središča. V akciji, ki je bila organizirana za našo deblokado, je bila formirana oklepna enota, sestavljena iz preostalega dela moje in Bjelovarske brigade. Ta enota je prišla $10 \mathrm{~km}$ pred Radgono, vendar je bila 3. julija zaustavljena v vasi Hrastje Mota, kjer so uničili vse tanke, ostalo je le nekaj transporterjev, ki so se na vrnitvi spojili z nami in se skupaj vrnili.

Moja enota je uspela realizirati nalogo kljub zelo visoki ceni. Pet ljudi je padlo, sedemnajst ranjenih, 25 zajetih. Uničeno je bilo 10 oklepnih in 12 motornih vozil. Ko sem se po vrnitvi srečal s Trifunovičem, sem videl, da je enako zmeden kot jaz. Nihče nas ni opozoril, da gremo v pravo vojno. S tako malimi silami proti nasprotni$k u$, ki je bil zelo dobro organiziran.

Po vrnitvi iz. Slovenije so se ljudje začeli spraševati in vsi mi smo preživeli svoje osebne drame. Čemu to žrtvovanje? Zakaj smo sploh šli v Slovenijo, če smo jo pozneje zapustili? Vsilila se je gora vprašanj in problemov. Položaj v Hrvaški pa se je pričel zaostrovati.«

Pripis:

$\mathrm{Z}$ določeno rezervo lahko razumemo zaključke polkovnika Popova, ki se nanašajo na enote JLA, ki niso bile pod njegovim poveljstvom. O njih je po vsej verjetnosti odločal general Trifunovič. Tu gre za kolono 10 tankov $v$ prvem delu vojne in za enote v drugem delu, ki so sodelovale pri deblokadi Popova. Glavnina vojakov v teh enotah je bila iz motorizirane brigade iz Bjelovarja. Tudi število mrtvih in ranjenih, ki ga omenja Popov, ni točno, saj gre pri tem za vojake pod njegovim poveljstvom (razvidno iz revije »Narodna armija $z$ dne, 10. 07. 1991, str. 22). Tu niso zajeti vojaki iz spopadov v Kačurah (našli okrvavljene obleke), Kogu (zadet tank), Presiki (Po dokaj zanesljivih podatkih so bili tu trije mrtvi in več ranjenih.), Gibini (v drugem delu vojne), Pristavi, Ljutomeru in Bučečovcih. Po podatkih, zbranih na $73 . \mathrm{Obm}$. ŠTO, je 12 pripadnikov JA padlo, ranjenih pa je bilo 32 vojakov.

Enote JLA so na območju 73. Obm. ŠTO doživele popoln vojaški poraz. Na koncu spopadov ni bil realiziran noben zastavljeni cilj. Doživele so tudi svoj moralni poraz. Ta poraz je imel kasneje tudi posredni vpliv na vojno na Hrvaškem.

\section{ANALIZA DELOVANJA TO NA OBMOČJU 73. OBM. ŠTO LJUTOMER}

\section{Stanje, 27. 6. 1991 ob 3.00 uri}

Vse enote na območju 73.Obm. ŠTO so bile mobilizirane. Pripadniki stalne sestave so bili razporejeni po načrtu v vseh treh poveljstvih. Enote razporejene v skladu $z$ načrtom Zamisel in razporeditev enot TO:

Enote v G. Radgoni so bile namenjene za blokado mejnega prehoda in stražnic ter obrambo mosta na reki Muri v Radencih, enote v Ormožu za obrambo mosta na Dravi v Ormožu in nadzor območja ter enote $v$ Ljutomeru za obrambo mostov na Muri $v$ Razkrižju in Veržeju, ostali del pa je predstavljal rezervo.

Napad 1. kolone JLA (27. 6. ob 6.30 uri)

Prvi spopad se je pričel 27. 6. 1991 v Ormožu. Mehanizirana oklepna kolona se je iz Varaždina premikala v smeri mesta Ormož. Ob 8.15 uri je prispela do mosta, ki je bil blo- 
kiran v skladu z načrtom. Prišlo je do razgovorov, ki so trajali do 12.00 ure. V njih so sodelovali $v$ začetku poveljnik protidiverzantskega voda Ivan Kuharič, komandirdir policije Jure Ferme, kasneje pa iz stalne sestave pomočnik poveljnika za operativne zadeve Aleksander Štampar in referent za pouk Branko Bratkovič. Okoli 13.00 je na pogajanje prišel poveljnik območja Ljubo Dražnik. Pogajanja ni opravil, ker je v tem času, že prišlo do prodiranja prek mostu in do oboroženega spopada ${ }^{5}$. Ker nasprotniku ni uspelo prebiti blokade na mostu, je poslal iz Varaždina drugo oklepno enoto prek Središča ob Dravi. Ta je poskusila osvojiti most v nasprotni smeri. Ker niso uspeli (niso upali prek branjenih ovir v mestu, okrepljenih z protipehotnimi in protioklepnimi minami), so po spopadu s skupino teritorialcev v središču mesta nadaljevali prodiranje po glavni cesti proti Ljutomeru.

Spopad v Ormožu je imel velik pomen. Tu se je prvič začelo streljati. Premagana je bila psihološka blokada glede uporabe orožja. Pokazalo se je, da se močnejšemu nasprotniku lahko upre. Pomeni pa tudi enega prvih večjih spopadov v začetku vojne $v$ Sloveniji (Polkovnik Popov omenja $\mathrm{v}$ svojih spominih ta spopad kot začetek vojne $\mathrm{v}$ Jugoslaviji NIN, 23. 2. 1996). V spopadu so razen treh vodov iz ormoške občine sodelovala še 1. in 4. vod jurišnega odreda (JOd) iz Ljutomera pod vodstvom Alojza Novaka.

Zamisel poveljnika območja za nadaljnjo obrambo je, po uspehu pri Ormožu, bila:

onemogočiti prehode prek Drave in Mure, z oviranjem in zasedami onemogočiti prodor proti Ljutomeru in z uvajanjem rezerve zaustaviti nasprotnika in ga prisiliti, da se vrne na Hrvaško

Napad 2. kolone JA (27. 6. 1991 ob 12.00 uri.)

Druga kolona je po neuspehu v Ormožu prodirala po glavni cesti Ormož - Ivanjkovci Ljutomer. Poveljnik območja Dražnik Ljubo je po dogovoru z načelnikom Mirkom Rautarjem in pomočnikom za zaledje Alojzom Novakom odločil, da se organizira obramba na območju Kačur in Mekotnjaka - gozd in manjše naselje neposredno pred Ljutomerom. Ovire so naredili iz navzkrižno podrtih dreves. Pri rušenju so bili v veliko pomoč delavci gozdnega gospodarstva. Na tak način so bile narejene tri ovire v Kačurah in ena v Mekotnjaku. S tem so bile zaprte vse poti do Ljutomera. Ovire je branil JOd iz Ljutomera (poveljnik Slavko Modlič). Do spopada na tem območju je prišlo 27. 6. $1991 \mathrm{v}$ večernih urah ob 22.00 uri. 28. 6. zjutraj je izvedla napad protioklepna skupina, ki jo je vodil Smiljan Kuhar. Z armbrustom je zadel tank Robert Gradiščaj. Uspeh je bil velik. Nasprotnik ni uspel napredovati in se je umaknil na Hrvaško. Doživel je izgube, zadet in delno onesposobljen je bil en tank. Največji pomen, ki ga ima ta spopad, so bile izkušnje v postavljanju priročnih ovir. Ta način oviranja je postal šolski primer za kasnejše oviranje, pozitivni rezultati pa so se kasneje pokazali v spopadih na Gibini, Banfiju, Presiki, Stara Nova vas, Pristavi in drugje.

Napad 3. kolone JLA (27. 6. 1991 ob 18.00 uri)

Tretja kolona iz Varaždina, je bila oklepno mehanizirana enota, ki jo je vodil polkovnik Popov. Premikala se je prek Hrvaške do Štrigove in od tam prek Banfija in Razkrižja napredovala ob Muri proti Gornji Radgoni.

5 V borbah v Ormožu je prišlo do prvega ranjenega na strani agresorja, tukaj je bil z armbrustom poškodovan prvi tank. Streljal je Branko Bratkovič. Kljub premoči nasprotniku ni uspelo priti preko mosta. To mu ni uspelo nikoli v desetdnevni vojni. 
Takrat sta bila dva voda iz ljutomerskega JOd v Ormožu, ostala dva voda iz JOd pa sta organizirala obrambo v Kačurah. Na na tem območju sta ostala samo protidiverzantski vod (na območju Gibina - Razkrižje) in pontonirski vod (v Veržeju pri mostu čez Muro) ${ }^{6}$. Kljub oviram v Razkrižju je 3. koloni uspelo v poznih urah priti pred Veržej, kjer je na odprtem, za naše pripadnike težko dostopnem mestu, prenočila. Z nalogo uničenja cisterne goriva je bila tja poslana skupina naših vojakov pod vostvom Alojza Novaka, ki pa v težkih vremenskih razmerah (noč, močno deževje) naloge ni uspešno opravila. Nočne razmere niso bile primerne za učinkovit napad.

Zjutraj je poveljnik Dražnik Ljubo poslal 2. protioklepno skupino pod vodstvom Branka Bratkoviča, ki je streljala na kolono JLA pri izhodu iz Veržeja, vendar je mina iz armbrusta zgrešila. Naslednji napad je izvedla protioklepna skupina diverzantskega voda iz Ljutomera med Veržejem in Bunčani. Izstrelili so dve mini iz protioklepnega orožja, vendar zgrešili cilj ${ }^{7}$.

Sovražni koloni je kljub oviranju ${ }^{8}$ in večurnih bojih v Gornji Radgoni ${ }^{9}$ uspelo pozno popoldne 28. 6. zasesti mejni prehod.

Borbe v Gornji Radgoni je imel velik psihološko propagandni pomen za Slovenijo. Mesto je bilo zelo porušeno. Svoje je naredila tudi bližina meje z Avstrijo. V spopadu v Gornji Radgoni sta izvajala širšo blokado mesta dva jurišna odreda. Diverzantski vod in protidiverzantski vod sta blokirala jedro Gornje Radgone. Za blokado mejnega prehoda so bili predvideni pripadniki policije.

Napad 4. kolone JLA (28. 06. 1991 ob 10.30 uri)

Četrta kolona je po neuspelem prehodu Mure pri Murskem Središču krenila proti Ljutomeru. Do spopada na Gibini je prišlo 28. 6. ob 18.30 uri.

Območje Gibina - Banfi - Razkrižje je branil protidiverzantski vod iz Ljutomera (poveljnik Vlado Kunčič), razdeljen na dve skupini in diverzantski vod (poveljnik Bogdan Vrbnjak) razdeljen na tri skupine. Na cesti Gibina-Razkrižje so bile tri ovire, ki so bile branjene po načelu zaporednih zased. Zasedo v Gibini je pripravila prva skupina protidiverzantskega voda. Razdelili so se v dva dela. Prvi je deloval pred kolono, drugi, s pehotnim orožjem, pa bočno. Napad so pričeli, ko je bil nasprotnik z vozili oddaljen od njih komaj 4 do $6 \mathrm{~m}$. Z močnim ognjem iz vsega orožja so zasuli nasprotnika in se hitro umaknili na drugi položaj. V tem spopadu je imel nasprotnik dva mrtva, na naši strani so bili ranjeni Vlado Kunčič, Branko Kaučič in Dušan Meško. Ta spopad se šteje na območju 73.štaba za enega najuspešnejših. Osem teritorialcev je pokazalo veliko hrabrost (posebej se je izka-

$6 V$ skladu z načrti, ki so bili narejeni pred vojno in odobreni s strani PŠTO je bila organizirana obramba na mostovih prek Mure. Predvidevali so poskus preboja. JLA čez. Muro in deblokado vojašnice v Murski Soboti.

7 Enote, ki so delovale na območju občine Ljutomer, so imele takrat na razpolago samo dva armbrusta, kar je bil glavni razlog, da nismo uporabili veř protioklepnega orožja, saj je bilo potrebno s tem orožjem ravnati skrajno racionalno.

$8 \quad$ V Vučji vasi in Hrastju je deloval 13. pontonirski vod.

$\checkmark$ Radencih se je 62. diverzantski vod pod vodstom Tomaža Zlatnika ob 9.00 uri spopadel s kolono .ILA. Spopad se je razširil po celem mestu. En civilist je pri tem izgubil življenje.

9 Pri industrijski coni v Gornji Radgoni je delovala protioklepna skupina pod vodstom Zvoneta Benka. $V$ borbah v Gornji Radgoni se je posebej izkazala skupina prostovoljcev TO z. uporabo molotovk. Izgube nasprotnika v materialno tehničnih sredstvih so bile velike. V tem spopadu je imel nasprotnik enega mrtvega in enega ranjenega vojaka. Tu je umil civilist.Janez. Svetina, svetovni popotnik in filozof. 
zal Milan Bolkovič). Nasprotnika so prisilili, da je odstopil od prodiranja proti Ljutomeru in nadaljeval premik po hrvaškem ozemlju prek Štrigove in Banfija.

$\mathrm{Na}$ Banfiju je organizirala obrambo druga skupina protidiverzantskega voda (poveljnik Bojan Bolkovič) in oddelek diverzantskega voda. Obrambo so pripravili na vrhu pobočja, kjer se cesta po ovinkih spušča proti naselju. Ta del ceste je bil močno oviran $z$ navzkrižno porušenim drevjem. Ob 21.40 je prišlo do ostrega spopada. Ker nasprotnik preko branjene ovire ni uspel prodreti, je poskusil prodor po poljski cesti preko Banfija do Veščice. Bojne aktivnosti so prenehali po objavljenem premirju.

\section{Premirje od 29. 6. do 2.7.1991}

Od 29. 6. do 2. 7.1991 je nastopil čas premirja. Enote TO so se po vseh naporih nekoliko odpočile in popolnile z orožjem in strelivom. Težišče je bilo na popolnitvi s protioklepnim orožjem. 29. 06. zvečer so sporočili iz Gornje Radgone, da enote JLA na mejnem prehodu opravlja prevoze do stražnice v Gornji Radgoni in nazaj. Hkrati je bilo javljeno, da se polkovnik Popov želi pogovoriti s poveljnikom območja. Zjutraj, 30.6 ob 03.30 uri, je poveljnik odločil, da ob 8.00 uri opravi prva pogajanja s Popovom in sicer v spremstvu skupine vojakov iz protidiverzantskega voda in 2. voda JOd iz Ljutomera (poveljnica, poročnik Jacqelina Steržaj). Iz Gornje Radgone je poklical poveljnika PŠTO Vlada Miloševiča in ga seznanil z razmerami in svojo odločitvijo. Poveljnik mu je pogajanja najprej odsvetoval, potem pa dovolil, s pripombo, da jih izvaja na lastno odgovornost. Pogajanja s polkovnikom Popovom so se začela ob 8.30 uri. Udeležila sta se jih Ljubo Dražnik in komandir postaje policije Gornja Radgona Stanko Sakovič. Čeprav niso uspela, je poveljnik območja dosegel, da so ostala vsa vozila JLA na mejnem prehodu. Dogovorili so se tudi o prevzemu mrtvega častnika JLA.

Operativno poveljstvo in enote, ki so bile v obrambi mesta Gornje Radgone, so bile potrebne strokovne in moralne podpore. Zato je Ljubo Dražnik odločil, da še isti dan pošlje v Gornjo Radgono načelnika Obm. ŠTO Mirka Rauterja z nalogo, organizirati osvobajanje mejnega prehoda. Takoj po prihodu v Gornjo Radgono se je začela organizacija blokade enote JLA na mejnem prehodu. Sodelovale so enote TO, policije in civilna obramba. Blokada je bila postavljena že 1.7 zjutraj. Vse je bilo pripravljeno za oborožen spopad, vendar zaradi priporočila lokalnih oblasti (možnost velikega rušenja in žrtev) do tega ni prišlo. Predlagana so bila pogajanja. Pričela so se 1. 7. ob 17.00 uri. Tedaj je prišel v Gornjo Radgono načelnik PŠTO Alojz Šteiner, ki je prinesel dodatna navodila za poveljstvo TO v Gornji Radgoni in imel pooblastilo državnega vodstva za odločitve na pogajanjih. Vendar niso dosegli napredka. Položaje TO v Gornji Radgoni si je ogledal tudi poveljnik PŠTO Vlado Miloševič.

Na Območnem poveljstvu Ljutomer se v času premirja organizira prerazporeditev enot, tako da je bila zagotovljena obramba na celotnem ozemlju in s tem minimalna možnost presenečenja s strani JLA. Prihajale so tudi nove pošiljke orožja. Predvsem protioklepno orožje je bilo potrebno razdeliti med enote in seznaniti v/o z njegovo uporabo. Po obvestilu zalednega organa 7. PŠTO so zaradi pomanjkanja streliva in minsko eksplozivnih sredstev (MES) začeli 2. 7. 1991 iz skladišča Ložnica pri Slovenski Bistrica voziti strelivo in MES (deset kamionov). Z delom prevzetega streliva in MES so dopolnili enote TO, del pa so skladiščili pri občanih v Gornji Radgoni in Ljutomeru. 
Velik problem in psihološki pritisk je predstavljala oklepno mehanizirana enota JLA, ki se je bila pred Središčem ob Dravi. Nenehno prižiganje in obračanje tankov je zahtevalo neprestano pripravljenost in budnost enot. Še posebej je to veljalo za enote $v$ ormoški občini. Podoben problem so ob prižiganju tankov imeli tudi v Gornji Radgoni.

$\mathrm{V}$ tem času so postavili veliko ovir na vseh pomembnejših komunikacijah. Na območju vasi Križevci so naredili veliko ovir iz palet opek, ki so se kasneje dobro izkazale.

Napad 5. kolone (2. 7. 1991 ob 13.00 uri)

Premirje je bilo končano 2. 7.1991 ob 13.00 uri. Takrat je krenila na pot peta oklepno mehanizirana kolona $\mathrm{z}$ nalogo, da prodre do Gornje Radgone in nato pomaga razbiti blokado okrog enote polkovnika Popova. V Slovenijo je prodrla mimo Središča ob Dravi in nato prek Vitana in Presike prodirala proti Ljutomeru.

Do prvega spopada je prišlo ob 18.45 uri v naselju Presika. Tam se je bil diverzantski vod (poveljnik Ljubo Smodiš) iz Ljutomera in skupina policistov, ki se je priključila k vodu. Civilisti iz bližnjih hiš so se že pred bojem umaknili na varno. Borba v Presiki je trajala približno dve uri. Nasprotnik je izgubil tank in 2 oklepna transporterja. V transporterju, ki je bil direktno zadet z ročnim protioklepnim orožjem iz razdalje približno $50 \mathrm{~m}$, so trije vojaki izgubili življenje, ostali so bili ranjeni. Tank in drugi oklepni transporter sta bila zadeta $v$ gosenice. $V$ tem spopadu sta se posebej izkazala vojak Miran Medvedar in policist Lichtervalner. Spopad je imel za nadaljnji potek spopadov s to kolono zelo velik pomen. Morala častnikov in vojakov te enote je zelo upadla. Kasneje je po celi poti število vozil in ljudi iz te enote stalno usihalo in so se predajali našim silam.

Kolona je potem nadaljevala pot do Stročje vasi, kjer je prenočila. Zjutraj 3. 7.1991 ob 3.30 uri je nadaljevala pot proti vasi Pristava, kjer je prišlo ob 4.00 uri do spopada s skupino protidiverzantskega voda. Naša enota je pripravila zasedo pri mostu čez reko Ščavnico. Na most so bila navožena priročna sredstva (les in tovornjak gramoza). Prišlo je do kratkega, vendar silovitega spopada, nakar se je skupina protidiverzantskega voda po ukazu umaknila na naslednji položaj v Ljutomer. Posledica tega spopada je, da so se na območju vasi Pristava vojaki JLA kasneje predali in zapustili tank in oklepni transporter.

Kolona je po tem spopadu prodirala proti Ljutomeru. V mestu Ljutomer je bil na položajih pred Stročjo vasjo poveljniški vod (15 vojakov z ročnim minometom poveljnik Jože Viher) in na drugi strani mesta pri obratu »MURA« oddelek proti diverzantskega voda (11 vojakov - poveljnik Milan Bolkovič). Ljutomer je bil takrat obkoljen s treh strani (deli enot JLA so se bili v Stročji vasi, Pristavi, del enot je prodiral iz smeri vasi Cven proti železniškem prehodu v Ljutomeru. Zato je takoj po spopadu v samem mestu poveljnik območja ukazal umik na pripravljeno rezervno poveljniško mesto (PM). V Ljutomeru so bili takrat samo poveljnik, tajnica in pet vezistov brez vsakršnega protioklepnega orožja. Ker je bila telefonska zveza na izpostavljenem poveljniškem mestu slaba, se je poveljnik vrnil v Ljutomer še v času spopada $v$ samem mestu in nadaljeval $\mathrm{z}$ vodenjem enot iz mirnodobnega sedeža poveljstva.

Do spopada na železniškem prehodu, kjer so postavili oviro iz železniških vagonov je prišlo ob 5.35 uri do medsebojnega obstreljevanja, ki je trajalo približno 3 ure. Enota JLA je svojo namero o prodiranju skozi mesto Ljutomer opustila in nadaljeva- 
la pot skozi Lukavce proti Križevcem. V Križevcih jih je v zasedi čakala druga skupina protidiverzantskega voda (poveljnik Vlado Kunčič). Do spopada ni prišlo, ker je večje število civilistov, predvsem otrok, prišlo na cesto gledat tanke in je bila velika možnost žrtev med civilnim prebivalstvom.

Do naslednjega spopada je prišlo v naselju Bučečovci ob 12.30 uri. Tam je bil JOd iz Slovenskih Konjic, ki je ponoči prišel na pomoč našim enotam. Oblikovali so protioklepno skupino (POS), ki je streljala na nasprotnika. V tem spopadu ni bilo poškodovano nobeno vozilo. Na tem območju je deloval tudi prvi vod tretjega JOd (poveljnik Zvonko Osterc) iz Ljutomera, ki je takrat sočasno streljal na nasprotnika, vendar brez večjega uspeha.

Zadnji spopad s to kolono se je zgodil ob 14.30 uri, ko je bil zadet oklepni transporter pred Radenci. Na tistem območju sta takrat delovala protidiverzantski vod iz Lenarta in protioklepna skupina PŠTO, med Radenci in Gornjo Radgono pa POS iz Murske Sobote.

Napad 6. kolone (2. 07. 1991 ob 13.00 uri)

6. kolona je delovala na smeri Železna gora - Martin ob Muri - Gibina, kjer se je ob 16.45 uri bojno razporedila. Območje Gibine se je takrat obvladoval 4. vod JOd (poveljnik Bojan Hladen) iz Ljutomera. Prišlo je do spopada, v katerem je bil en tank lažje poškodovan zadetek $\mathrm{z}$ armbrustom. Nasprotnik je tu napadel kombinirano $\mathrm{s}$ tanki in pehoto. Tanke je zaustavila škarpa pred vasjo, medtem je pehota poskusila skleniti obroč okrog našega voda, ki pa se je pravočasno umaknil na naslednji položaj. Po tem spopadu, kjer so bili zelo poškodovani tudi civilni objekti, se je enota JLA umaknila v Štrigovo in pozno zvečer pričela prodirati proti Banfiju, kjer pa je bila zaustavljena na branjenih ovirah. Po tem spopadu je ta enota svoj prodor proti Sloveniji ustavila in se vrnila na Hrvaško.

\section{Napad 7. kolone (3. 7. 1991 ob 2.30 uri)}

7. kolona je ponoči 3. 7. ob 2.30 uri začela prodirati od Središča ob Dravi prek Vitana v smeri Kog - Presika. Na tistem območju sta bila 1. vod (poveljnik Emil Škrinjar) in protidiverzantski vod (poveljnik Milan Korotan). Koordinacijo med njima je vodil pomočnik poveljnika za operativne zadeve Aleksander Štampar.

Iz 1. voda so ustanovili POS, ki je pripravila zasedo v rajonu Bajzek. Ob 10.30 uri je prišlo do spopada v katerem je bil en tank zadet v kupolo in onesposobljen. Drugi tank je pri tem spopadu zavil s ceste in zdrsnil pod škarpo. Ker ga niso mogli izvleči, so ga vojaki zapustili. Po tem spopadu se je nasprotnik vrnil na Hrvaško in ob tem streljal in razdejal civilne objekte v vaseh Kog, Jastrebci in Bajzek.

\section{Spopad v Gornji Radgoni (2. 7. 1991 ob 16.00 uri)}

V torek, 2. 7. so se v Gornji Radgoni pospešile priprave za oborožen spopad. Ob 7.30 uri so teritorialci dobili ukaz za najvišjo stopnjo bojne pripravljenosti. Vse enote (okoli 420 teritorialcev) so bile na položajih okoli mejnega prehoda že tretji dan. Tedaj je bilo vsem jasno, da mirna rešitev umika JLA ni več mogoča. Ob 14.30 uri je načelnik Obm. ŠTO Mirko Rauter, ki je vodil operacijo v Gornji Radgoni, dobil pisni ukaz za napad na enoto JLA v primeru, da se ne preda. Ukaz je posredoval poveljnik višjega poveljstva Vlado Miloševič.

Radioamaterji so okoli 15.00 ure prestregli sporočilo Popova po radijski zvezi med oklepniki; »Prvi cilj pod brezo«. Pozneje je bilo jasno, da je to cerkveni zvonik, kajti ob 16.15 se je začelo streljanje. Teritorialci so udarili iz svojih položajev na Grajskem 
hribu z zoljami, ročnimi minometi M 57 in OSA, vojaki JLA pa iz topov in mitraljezov po mestu. Takoj po začetku spopada se je oglasila tudi sirena za letalsko nevarnost. Položaje teritorialcev sta preleteli dve letali JLA, ki sta raketirali položaje in barikado na železniškem prehodu pri Avtoradgoni. Radgona je bila naenkrat v dimu in ognju. Slišalo se je pokanje orožja in tuljenje gasilskih siren. Spopad je trajal neprekinjeno do teme (do približno 21.00 ure). V spopadu je bil težje ranjen en teritorialec. Popolnoma je bil uničen cerkveni zvonik, zgoreli sta dve stanovanjski hiši na hribu. Okolica mejnega prehoda je bila popolnoma uničena. O številu žrtev pri JLA se ni nikoli izvedelo. Še pred večerom se je predalo tudi moštvo iz obmejne stražnice v Gornji Radgoni (Napad je izvedla enota policije in oba diverzantska voda TO iz Gornje Radgone.). Tako je TO zopet prišla do svojih skladišč in odstranila nasprotnika za hrbtom. Ponoči z 2. na 3. 7. je spet prišlo do premirja, vendar so teritorialci ostali na položajih.

V spopadu na mejnem prehodu so teritorialci dokazali veliko pripravljenost za oborožen boj in dosego interesov samostojnosti Slovenije. Ta spopad je prepričal tudi tako trdega oficirja, kot je bil Popov, da se bo slej ko prej moral umakniti. Računal je lahko še samo na pomoč enot, ki so 2. 7. začele prodirati prek meja Slovenije. Ko pa tudi tem ni uspelo, je Popov končno 3. 7. popoldne na pogajanjih pristal na umik. Odločitev o tem, da se lahko umakne z ljudmi in opremo, je bila sprejeta na višjem poveljstvu. Enota JLA je za sabo pustila razdejani in izropani mejni prehod. Dosežen je bil eden izmed največjih uspehov vojne v Sloveniji, to je osvobojena Gornja Radgona.

\section{Zaključna ocena vodenja in delovanja enot in pripadnikov $\mathrm{TO}$ :}

Pozitivni učinki:

- Preprečitev nasprotnikovega cilja.

- Skrb življenja borcev TO.

- Upoštevanje pokritosti celotnega območja in preprečevanje vojaškega presenečenja.

- Zbijanje morale nasprotnika

- Racionalna in učinkovita uporaba rezerve.

- Velika samostojnost enot pri izvajanju bojnega delovanja.

- Elastičnost pri zamenjavi in nadomeščanju starešin stalne sestave.

- Učinkovito izvajanje protioklepne borbe.

- Pogum in hrabrost pripadnikov TO.

- Uspešno vodenje in poveljevanje je kljub manjšim pomanjkljivostim.

- Poznavanje ozemlja zagotavljalo uspešno izvajanje bojnega delovanja.

- Prehod od obrambnih v napadna bojna delovanja.

- Dvig bojne morale pripadnikov TO po uspehih.

- Uspešno in dobro sodelovanje s policijo.

- Sodelovanje s civilno obrambo, Posebej velja za pomoč pri oviranju, prehrani, nastanitvi, zdravstveni oskrbi, prevozih in nekaterih oblikah zaledne zagotovitve.

- Dobra organizacija in skrb za vojne ujetnike $v$ sodelovanje $z$ rdečim križem in policijo.

- Sodelovanje $\mathrm{z}$ društvi. Posebej velja to za gasilska društva, radioamaterje in $\mathrm{v}$ Ljutomeru lovska društva, ki naj bi v skladu z mednarodnim vojaškim pravom sodelovali v primeru protipehotnega boja kot prostovoljci TO. 
Negativni učinki:

- Preveliko število samostojnih enot je zahtevalo organizacijo dveh izpostavljenih PM.

- Sistem zvez je bil v glavnem odvisen od civilnega telefonskega omrežja.

- Koordinacija med policijo in TO ni bila zadostna, kar bi lahko pripeljalo do nesreč.

- Sodelovanje med enotami TO je bilo premajhno.

- Nepoznavanje novega orožja je zmanjševalo bojni učinek enot TO.

- Nekatere starešine TO niso izvedle bojnega streljanja s PO orožjem, zato večkrat niso odstranili varoval na tromblonskih minah.

- Prihod enot iz drugih krajev Slovenije v času spopadov in nepoznavanje ozemlja ter takojšnja vključitev v obrambne aktivnosti so zmanjšale njihovo učinkovitost in bojno uporabo.

- Vključevanje PŠTO v poveljevanje v Ormožu in Gornji Radgoni je imelo za posledico preveliko zgostitev sil TO v teh mestih in premajhno rezervo območja.

- spopadi v naseljenih krajih so zahtevali veliko opustošenje civilnih zgradb.

\section{ZAKLJUČEK}

V junijsko - julijski vojni je 73. Obm. ŠTO imel pomembno nalogo. Kljub temu da je nasprotnik razpolagal $s$ tanki, moderno oborožitvijo in po ognjeni moči daleč presegal možnosti TO je enotam 73. Obm. ŠTO uspelo zaustaviti šest oklepnih kolon od sedmih, ki so prodirale prek tega območja. Posledice za prebivalstvo in naselja bi bile dosti hujše, če bi agresorske enote prodrle globlje v notranjost. Ta uspeh je bil odraz poguma in pripravljenosti pripadnikov TO braniti svoj dom in odraz neposrednega in dobrega sodelovanja $\mathrm{s}$ prebivalstvom, oblastnimi organi, policijo, podjetji in drugimi.

O intenziteti spopadov govori tudi tragična bilanca. Na območju 73. Obm. ŠTO je bilo uničenih in poškodovanih 6 tankov, 5 oklepnih transporterjev, 9 tovornjakov, 2 cisterni in 5 terenskih vozil. Padlo je 12 vojakov, 32 jih je bilo ranjenih, na koncu vojne je TO zajela dva tanka in 3 oklene transporterje, ki so bili sposobni za oborožen boj, in en helikopter MI - 8. Na strani TO je bilo 7 ranjenih, 2 civilista sta bila ubita.

\section{VIRI:}

- Dražnik, L., 1991: Zapiski dogajanj, Službeni zvezek, ki ga je v času vojne 1991 vodil poveljnik območja. Zvezek je pri avtorju tega prispevka.

- Dražnik, L., 1991: Zapisniki ustnih pričevanj udeležencev spopadov, ki jih je organiziral avtor prispevka zaradi razjasnitve določenih nejasnih vprašanj. Zapiski iz teh pričevanj so pri avtorju tega prispevka.

- Kern, J., 1995: Iz dnevnika slovenskega obveznika JLA, Mohorjev koledar, str. 186 - 192.

- Marjanovič, M., 1991: Žrtve na ratnom zadatku, revija »Narodna armija«, Beograd, 10. 7. 1991, str. 22.

- Popov, B., 1996: Započeo sam rat u Jugoslaviji, Častnik NIN, št. 2356, Beograd, str. 51 - 58.

- 73. Obm. ŠTO, 1991a: Pisni dokumenti (ukazi, navodila, zahtevki in druga bojna dokumentacija iz časa vojne). Arhiv 73. Poveljstva.

- 73. Obm. ŠTO, 1991b: Poročilo 73. Obm. ŠTO o uporabi PO orožja v času vojne, št. 2-80403/248 z dne, 4. 7. 1991, Arhiv 73. Poveljstva.

- 73. Obm. ŠTO, 1991c: Redna dnevna poročila v času vojne, št. 804-03/52 - 62. Arhiv 73. Poveljstva.

- 73. Obm. ŠTO, 1991d: Zaključki iz analize vojne na območju Prlekije na posvetu s poveljniki enot na območju 73. Obm. ŠTO, ki je bila 5. 8. 1991, Arhiv 73. Poveljstva.

- 73. Obm. ŠTO, 1992: Zaključki iz ponovne analize s poveljniki, ki je bila 27. 8. 1992. Arhiv 73. Poveljstva. 
Karta št. 1: Spopadi v prvem delu vojne (od 27. do 29. 6. 1991)

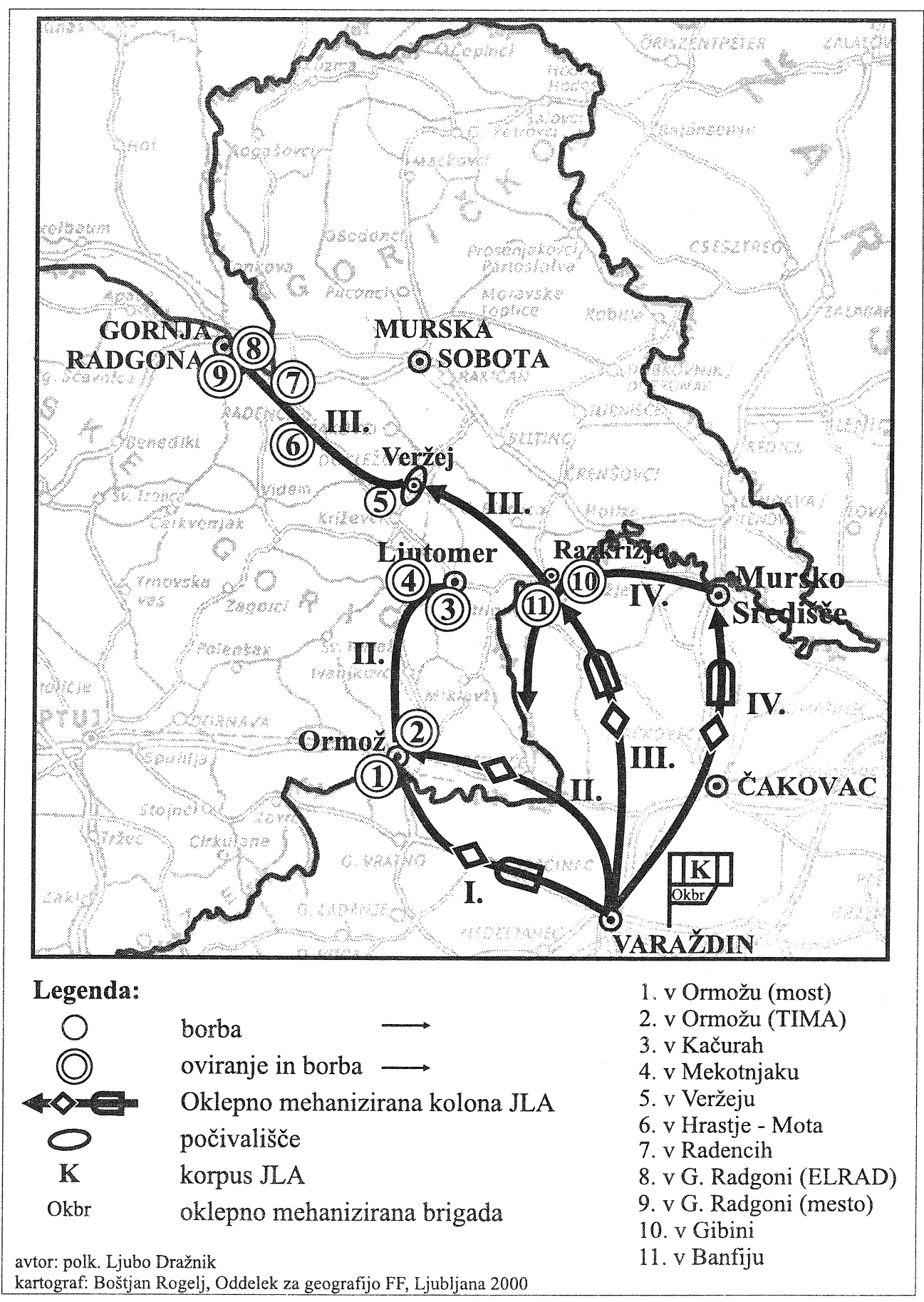


Karta št. 2: Spopadi v drugem delu vojne (od 27. do 29. 6. 1991)

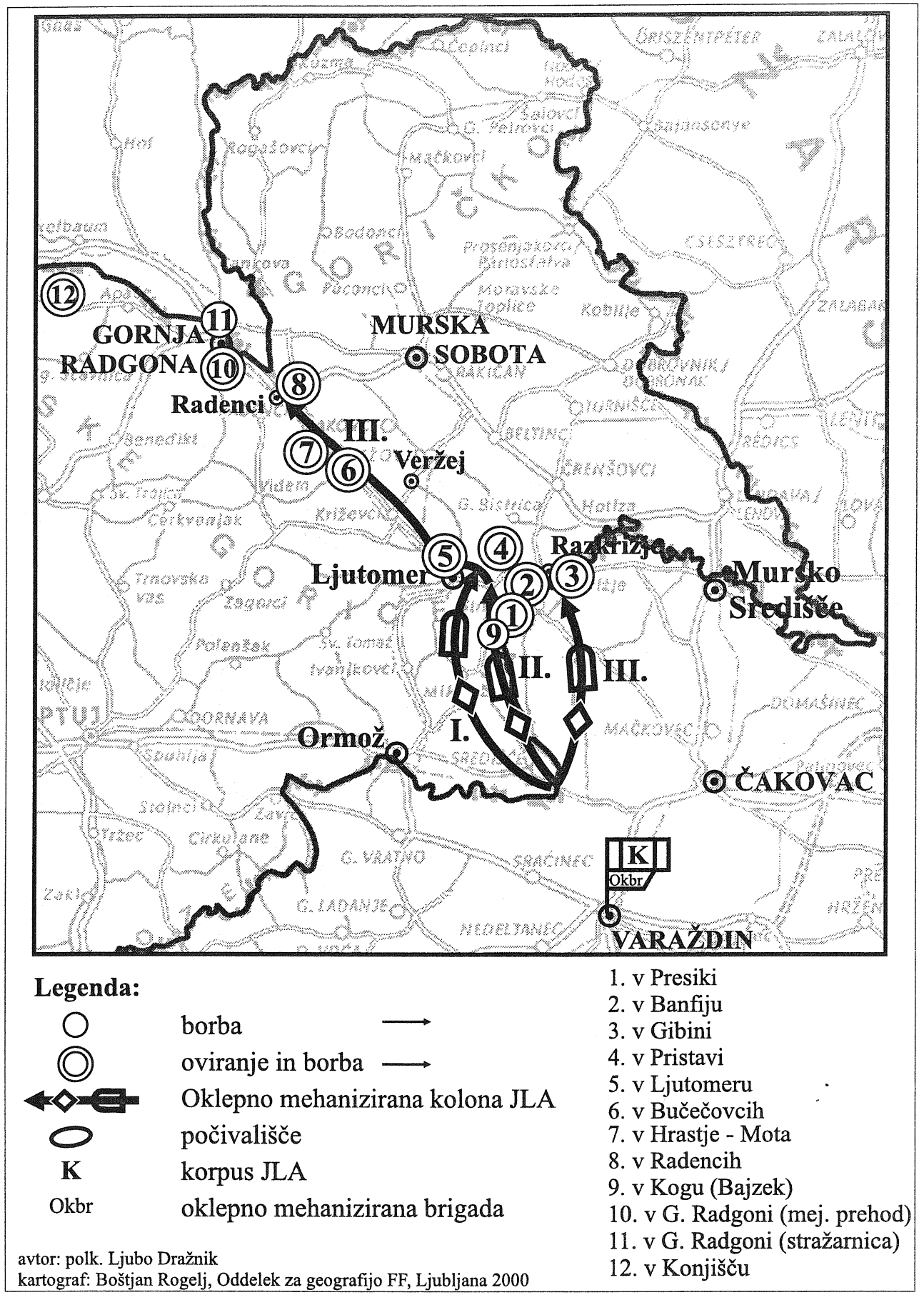

